\title{
Christ and His Representation, One or Two? The Image Theologies of Theodore of Stoudios, Leo of Chalcedon and Eustratius of Nicaea
}

\author{
Dirk Krausmüller | ORCID: 0000-0001-6978-1093 \\ Member of the project "Mobility and Migration in Byzantium", Universität \\ Wien, Wien, Austria \\ dkrausmuller@hotmail.com
}

\begin{abstract}
This article discusses the image theologies of Theodore of Stoudios, Leo of Chalcedon and Eustratius of Nicaea. It focuses on two topics: the relation between archetype and image and the identity of hypostasis. It is argued that Theodore's image theology was contradictory, and that Leo of Chalcedon and Eustratius of Nicaea each developed one aspect of Theodore's argumentation while neglecting the other.
\end{abstract}

\section{Keywords}

hypostasis - Iconophile - relation - Theodore of Stoudios - Leo of Chalcedon Eustratius of Nicaea

Today the worship of images of Christ and the saints is an integral part of the orthodox faith. Yet this had not always been the case. From 730 to 787 and again from 815 to 843 the emperors lent their support to clergymen who considered the practice to be idolatrous. Even during those years, however, there was opposition to the official line. One important player in the controversy was Theodore of Stoudios who in his letters and treatises presented arguments in favour of the cult of images. In the late eleventh century these arguments were reformulated by the metropolitan Leo of Chalcedon who accused the patriarch of the time of being an Iconoclast. Leo was in turn attacked by a cleric named Eustratius who also claimed to follow the footsteps of the Fathers. This article offers an analysis of the writings of the three men, with a focus 
on two notions: the relation between image and archetype and the identity of hypostasis. It is in part a retractatio of an earlier article on the same topic. ${ }^{1}$ There I had argued that Theodore held the same views as Leo. Yet the evidence does not bear out this interpretation. It is rather the case that Leo isolated one strand of Theodore's reasoning and took it to its logical conclusion.

\section{$1 \quad$ Theodore of Stoudios}

Theodore, the abbot of the Constantinopolitan monastery of Stoudios, was a fierce defender of image worship. When in 815 Iconoclasm again became the official doctrine of the state he openly declared that the emperor and the new Iconoclast patriarch were heretics. As a consequence, he suffered banishment, imprisonment and torture. ${ }^{2}$ Yet even under such adverse circumstances he did not cease to speak out. He wrote letters and treatises in which he explained why images must be worshipped and why the arguments put forward by the Iconoclasts were invalid. One burning issue was the materiality of images. The interaction with them was intensely physical: they were not only contemplated but also kissed and caressed. ${ }^{3}$ According to the Iconoclasts, this showed that the Iconophiles worshipped material objects. Theodore had to exclude such a possibility at all costs. In Letter 546 , which is addressed to the grammarian John, he sets out his own point of view.

And truly one must give veneration to the image of Christ not as matter, but as Christ himself, if indeed the honour accorded to the image ascends to the prototype, whereby the matter is eliminated through a mental operation from the imprint that is shaped in it. ${ }^{4}$

1 D. Krausmüller, 'Adoring Christ's image: The icon theology of Leo of Chalcedon and Theodore of Stoudios', Greek, Roman, and Byzantine Studies, 58 (2018), pp. 423-444.

2 On Theodore's life and works see Th. Pratsch, Theodoros Studites (759-826) zwischen Dogma und Pragma. (Berliner Byzantinische Studien 4; Berlin, 1998). See also G. Fatouros, Theodori Studitae Epistulae, 2 vols (Corpus Fontium Historiae Byzantinae, 31, 1-2; Berlin, 1991), vol. I, pp. $3^{*}-42^{*}$.

3 See M.-F. Auzépy, 'L'iconodoulie: défense de l'image ou de la dévotion à l'image', in Nicée II: 787-1987: 12 siecles d'images religieuses. Actes du colloque international Nicée II, tenu au Collège de France, ed. F. Boespflug and N. Lossky (Paris, 1987), pp. 157-165.

4 Theodore of Stoudios, Letter, 546 (to John Grammatikos), ed. Fatouros, vol. II, p. 826, 1l. 12-18.

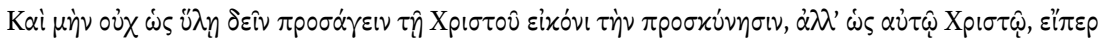

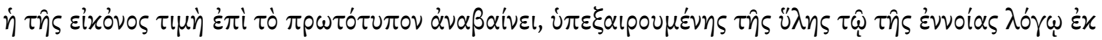

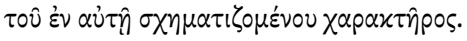


Theodore is adamant that the material aspect of the image is not to be venerated. He demands from the faithful that they mentally abstract the representation of Christ from the wood and paint from which it has been created. ${ }^{5}$ The representation can be venerated because there exists a bond between it and Christ himself. Theodore speaks of a transmission of honour, thereby alluding to a statement of Basil the Great, which had already been quoted in the Acts of Nicaea II as justification for the veneration of images. ${ }^{6}$

This still left the question: what kind of veneration should one offer to the representation of Christ? In Letter 447, which is addressed to his spiritual son Severianus, we find Theodore's most explicit statements. Severianus had made two claims: firstly, that 'the image of Christ is not venerated relationally' and secondly, that 'Christ is adored in his image, so that the image is adorable.' In his response, Theodores affirms that the concept of relation correctly describes the bond between Christ himself and his representation. He accuses Severianus of ignorance and then proceeds to set out his understanding of relational veneration.

Relation belongs to the relatives, and relatives are the prototype and the derivate, that is, Christ and his image, because one inheres in the other and is not cut off either as regards power or as regards glory. ${ }^{8}$

This is a clear reference to Aristotle's Categories, which has already been highlighted several times in scholarly literature. ${ }^{9}$ Relatives are terms such as father and son or master and slave, where one term can only be used in conjunction

5 See K. Parry, Depicting the Word:Byzantine Iconophile Thought of the Eighth and Ninth Centuries (Leiden, 1996), p. 172; T. Tollefsen, St Theodore the Studite's Defence of the Icons. Theology and Philosophy in Ninth-Century Byzantium (Oxford, 2017), p. 117; and M. Bratu, 'Quelques aspects de la théorie de l'icône de S. Théodore Stoudite', Revue des Sciences Religieuses, 77 (2003), pp. 323-349, at p. 342.

6 Basil of Caesarea, De Spiritu Sancto, 18, ed. B. Pruche, Basile de Césarée, Traité du Saint-Esprit (Sources Chrétiennes, 17; Paris, 1946), p. 406. See Bratu, 'Quelques aspects', p. 340, n. 97.

7 Theodore of Stoudios, Letter 445 (to Severianus), ed. Fatouros, vol. II, pp. 628, ll. 15, 22-23: Oن

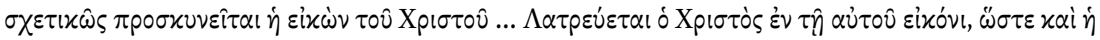

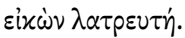

8 Theodore of Stoudios, Letter 445 (to Severianus), ed. Fatouros, vol. II, p. 628, ll. 16-19: 'H $\sigma \chi \varepsilon \dot{\varepsilon} \sigma \varsigma$

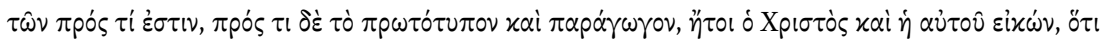

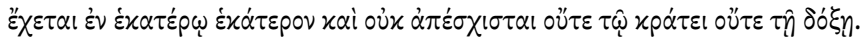

9 See Ch. Erismann, 'Venerating Likeness: Byzantine Iconophile Thinkers on Aristotelian Relatives and Their Simultaneity,' British Journal for the History of Philosophy, 24 (2016), pp. 405-425; and Tollefsen, St Theodore, pp. 99-100. 
with the other: there is only a father if there is also a son and vice versa. ${ }^{10}$ Yet it is clear that for Theodore relation establishes a much closer bond than Aristotle had envisaged. In a Christian context this was not surprising. Already in the fourth century Father and Son had been defined as relatives, with the express purpose of establishing their consubstantiality. ${ }^{11}$ Theodore's further claim that Christ and his representation are in one another also has a basis in Christian thought. It refers to the concept of coinherence, which had its place in Trinitarian theology and was justified by Christ's claim in the Gospel of John that the Son was in the Father and the Father was in the Son. ${ }^{12}$ Even so, however, the distinction between Christ and his representation remains, just as in Trinitarian theology the distinction between the Father and the Son is preserved. Therefore Theodore rebuts Severianus' claim that the image of Christ should be adored.

Adoration, just like faith, is given only to the Holy Trinity, and the others (sc. venerations) are given to others, to the Mother of God, to the lifegiving cross, to the revered image of Christ and to all other sanctifying images, and to the same degree as the prototypes have a higher status than the respective derivates. ${ }^{13}$

This is a very clear statement. Adoration can only be given to God in his three hypostases Father, Son and Spirit. By contrast, representations of Christ must be venerated since they are ontologically inferior. In this respect they do not differ from the images of the saints even though the saints themselves are human whereas Christ himself is divine as the incarnated Son of God. ${ }^{14}$

Letter 447 is not the only text where Theodore makes such statements. In Letter 476 , which is addressed to the spatharios Nicetas, he again affirms that adoration can only be given to the Trinity and then proceeds to speak about relational veneration.

10 See e.g. O. Harari, 'The Unity of Aristotle's Category of Relatives', The Classical Quarterly, 61 (2011), pp. 521-537.

11 See e.g. L. Turcescu, Gregory of Nyssa and the Concept of Divine Persons (Oxford, 2005), pp. $82-85$.

12 See e.g. G. L. Prestige, God in Patristic Thought (London, 1964), pp. 29o-292.

13 Theodore of Stoudios, Letter 445 (to Severianus), ed. Fatouros, vol. I, p. 628, ll. 22-31:

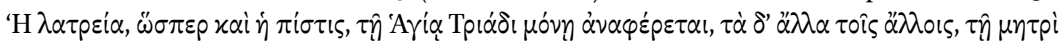

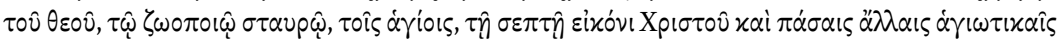

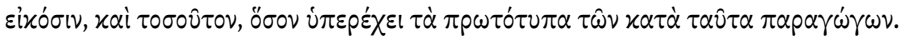

14 See Parry, Depicting the Word, p. 172. 
But one must venerate the image of Christ through relational veneration and that when we venerate it we venerate Christ, who is not separated as regards hypostasis but differentiated as regards the account of substance. ${ }^{15}$

In this case, however, Theodore does not respond to a heretical position but rather defends himself against criticism. An Iconophile bishop had claimed that he was deifying the image of Christ'.16 At a first glance this accusation seems unjustified. As we have seen in Letter 447, Theodore does not even concede a difference between images of Christ and images of the saints.

Yet Theodore's position is not as clear cut as it may seem. At the end of the passage he affirms that Christ and his representation are linked through hypostasis. This notion is elaborated in Letter 57, which Theodore addressed to his uncle Plato.

In the case of the natural image and the cause, that is, the Son and the Father, there is one veneration as there is one nature, according to the identity of nature but not of hypostasis.... But in the case of the mimetic image and the archetype, that is, the image of Christ and Christ, since there is one hypostasis of Christ, there is here also one veneration, according to the identity, that is, of the one hypostasis, not the alterity of the natures of Christ and of the image. ${ }^{17}$

Here the identity of archetype and image is affirmed in the strongest terms: both are the same because they are one hypostasis. The difference is restricted to the substantial aspect: the matter of the image has nothing in common with the divine substance, which is immaterial. In order to reinforce this point Theodore even draws a parallel with the relation between the divine persons: as the Father and the Son have the same substance, which makes them one

15 Theodore of Stoudios, Letter 476 (to Nicetas), ed. Fatouros, vol. II, p. 686, 1l. 19-23: Tìv

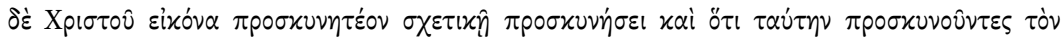

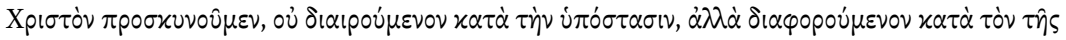

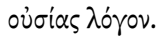

16 Theodore of Stoudios, Letter 476 (to Nicetas), ed. Fatouros, vol. II, p. 686, ll. 15-16:

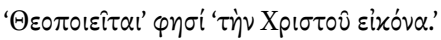

17 Theodore of Stoudios, Letter 57 (to Plato), ed. Fatouros, vol. I, pp. 165-166, ll. 44-53: 'E $\pi \grave{\mathrm{i}}$

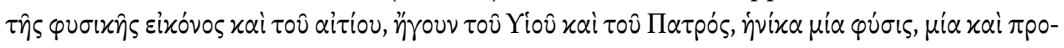

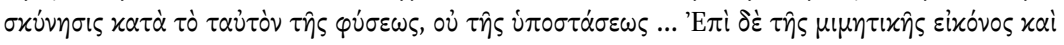

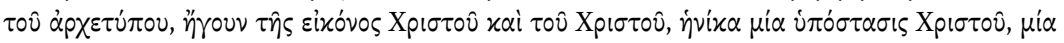

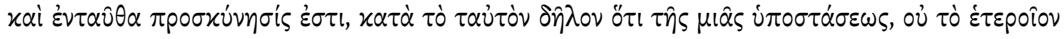

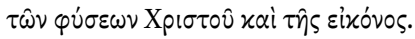


God, so Christ and his representation have the same hypostasis, which makes them one Christ. ${ }^{18}$ The identity of veneration would then be the logical corollary. Although Theodore uses the term veneration in this context one can only draw the conclusion that the representation of Christ can be offered adoration since the hypostasis of Christ as the incarnated Son is divine. Yet this is never spelt out. In the following passage Theodore backtracks again.

And to be concise: what is adored is not the image of Christ but Christ who is venerated in it, and one must venerate it according to the identity of the hypostasis of Christ, besides the difference of the substance of the image. ${ }^{19}$

This is quite a complex argument, which needs to be unravelled with care. We are told that Christ himself can be adored as he is God. Yet this adoration is not offered through the image since the representation of Christ can only be venerated. Such a position would be in keeping with Theodore's argument in Letter 447. Yet this is not his last word. Here, too, he avers that the difference is restricted to the material aspect. By contrast, Christ and his representation are identical.

It is difficult to see how the difference between prototype and derivate can be upheld. Indeed, another, very similar passage in Letter 546 shows that Theodore was prepared to jettison it.

One must, then, venerate the image of Christ but not adore it, but (sc. one must adore) Christ who is venerated in it according to the word of truth,

18 This point is made very clearly by Bratu, 'Quelques aspects', p. 341: 'Licône du Christ est le Christ'. Less clear is Parry, Depicting the Word, pp. 58-62, who states that 'the identity between the image and its prototype is an hypostatic one'. Hypostatic identity is rejected by Tollefsen, St Theodore, p. 123, in response to Th. Damian. The Icons: Theological and Spiritual Dimensions According to St. Theodore of Stoudion (unpublished dissertation: Fordham University, 1993), pp. 244-245. I would argue that for Theodore there exists an absolute identity between Christ and his representation. As Basil Lourié has pointed out to me, in contemporary philosophy this concept has come under criticism. See the entry 'Relative Identity' in the Stanford Encyclopedia of Philosophy: (https://plato.stanford.edu/ entries/identity-relative/). Accessed 13/11/2020. Yet it seems to me problematic to apply modern concepts to medieval texts. Moreover, the comparison with consubstantiality, which for Christians denotes the highest degree of oneness, seems to rule out the option of a lesser kind of identity.

19 Theodore of Stoudios, Letter 57 (to Plato), ed. Fatouros, vol. I, p. 168, ll. 110-113: Kai

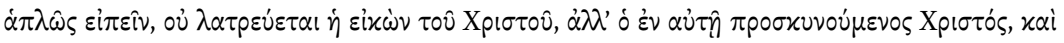

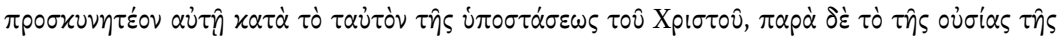

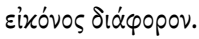


since these are two, the image and the prototype, and the difference is not in the hypostasis but as regards the account of substance. ${ }^{20}$

Here, too, Theodore begins by affirming the duality of Christ and his representation, which is the basis for relational veneration. Yet then he adds that this duality is restricted to the material aspect. It is evident that if the representation is the same as Christ himself it can be adored just like him.

The ambivalence of Theodore's position is also evident in his Third Antirrheticus where he seeks to rebut the Iconoclasts' contention that the Iconophiles introduced two types of worship of Christ: relational veneration and adoration. In his response he has the following to say.

If because we accord veneration to God alone, one must not venerate the image of Christ, since two venerations would be introduced besides the one, which is adorational, according to the duality of image and prototype, then there will consequently also be a dual veneration of the Father and the Son because of the duality of hypostases. But if to say this is impious, for it is one and the same, according to the singularity of nature, there is consequently one veneration of Christ and of his image, according to the singularity of hypostatic resemblance, but not according to the qualitative difference of natures. ${ }^{21}$

Theodore begins by summarising his opponent's argument: since image and prototype differ from one another there must also be two different venerations. As we have seen this is a problem that worried Theodore greatly. Significantly, in this case he does not distinguish between the adoration of Christ himself and the veneration of Christ's representation. Instead, he makes a comparison with the Trinity. The Father and the Son have different hypostases but they are venerated as one because of the one divine nature. In the same manner the prototype and the image have two substances but they are venerated as

$20 \quad$ Theodore of Stoudios, Letter 546 (to John Grammatikos), ed. Fatouros, vol. II, p. 827, ll.

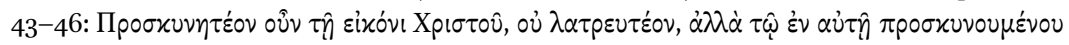

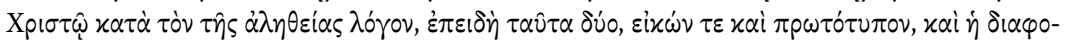

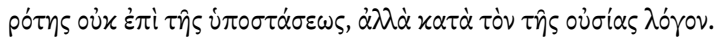

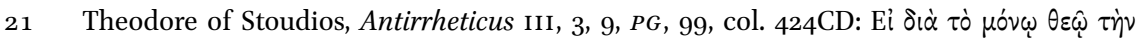

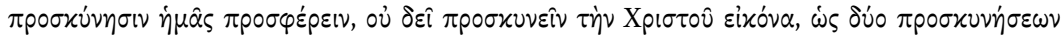

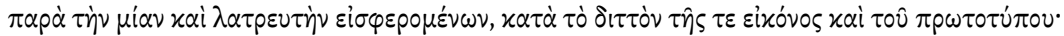

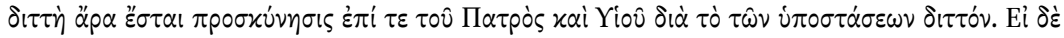

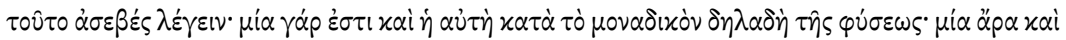
$\dot{\eta}$ X

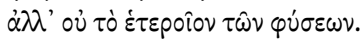


one because of the one hypostasis. This one veneration can logically only be adoration.

Time and again Theodore comes close to saying that the representation can be adored without ever spelling it out. Another example of this prevarication can be found in Letter 57 .

But if again someone said that the veneration of the image to the archetype is based neither on the identity of hypostasis nor on the identity of nature, it is obvious that he has cut asunder the power and divided the glory of the archetype from the image, and thus venerating the image of Christ he is manifestly an idolater, introducing not one but two venerations, which the image-fighters strive to demonstrate. ${ }^{22}$

Here, too, Theodore seeks to rebut the Iconoclast argument that he introduces two venerations. He avers that this would only be the case if Christ and his representation were two different hypostases. Then he makes the further claim that in such a case image worship would be idolatry. This is at odds with his claim that the image itself is only venerated but not adored even when there is sameness of hypostasis.

Indeed, there is no sign that Theodore had developed an overarching conceptual framework in which his different arguments could find their place. A passage in Letter 546 shows that he had reached an impasse.

It is not permitted to say that the sacred image of Christ is adorable, for then one of two things would be the case: either what is adorable in it would be added to the adoration of the Trinity, which is impossible (since it is not allowed to introduce an addition to the Trinity, for it will be found to be a quaternity), or when it is not added there but is adorable by itself, one would put forward the doctrine that our adorations are two. And what else would the pagan icon-fighters ask from us, but that we demonstrate in this manner that we adore with dual adoration, the creation instead of the creator. ${ }^{23}$

22 Theodore of Stoudios, Letter 57 (to Plato), ed. Fatouros, vol. I, p. 166, 1l. 65-67: Eì $\delta \dot{\varepsilon} \mu \varphi^{\prime} \tau^{\prime} \alpha \hat{\vartheta}$

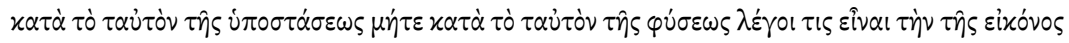

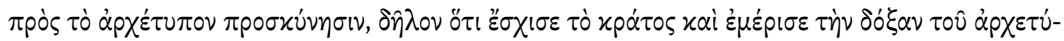

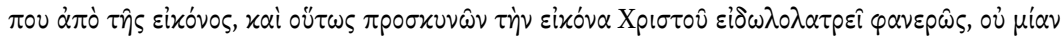

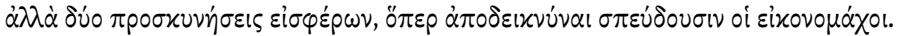

23 Theodore of Stoudios, Letter 546 (to John Grammatikos), ed. Fatouros, vol. II, pp. 826-827,

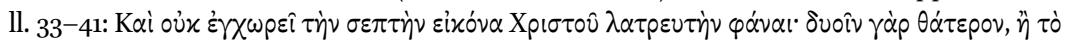

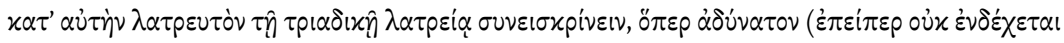

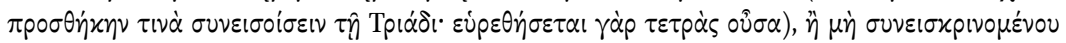


Here Theodore distinguishes between two options - the representation is adored as part of God, or the representation is adored by itself - and then concludes that both need to be rejected. It is immediately evident that the second option can be ruled out. Were it accepted it would lead to idolatry. By contrast, Theodore's treatment of the first option is less straightforward. He imagines a situation where the representation would become a fourth hypostasis beside the Father, the Son and the Spirit. This is clearly at odds with his claim that Christ and his representation constitute one hypostasis, the hypostasis of the divine Son who had become incarnate. This reticence is significant since the problem had already been dealt with in the Christological controversies of the fifth century. According to Chalcedonian orthodoxy, Christ's human nature was not a separate hypostasis, but an intrinsic part of the hypostasis of the divine Son, so that it could be adored as God. ${ }^{24}$

It was to take almost three hundred years until Theodore's argument was taken to its logical conclusion. This was the achievement of Leo, the metropolitan of Chalcedon. ${ }^{25}$ Leo lived at a time of political upheaval when the empire was assaulted by enemies from West and East. In order to finance his campaigns Emperor Alexius I ordered that objects made of precious metal be taken from churches and melted down even if they bore representations of Christ. ${ }^{26}$ Leo claimed that those responsible for the measure were Iconoclasts. In letters to the patriarch and to a fellow-metropolitan he declared that destruction of images of Christ was an attack on Christ himself. ${ }^{27}$ In order to justify this view, he developed an elaborate icon theology.

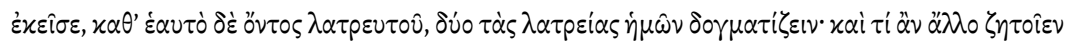

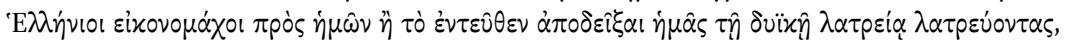
$\tau \hat{\eta} \varkappa \tau i \sigma \varepsilon l \pi \alpha \rho \dot{\alpha} \tau \dot{\partial} \nu x \tau i \sigma \alpha \nu \tau \alpha$.

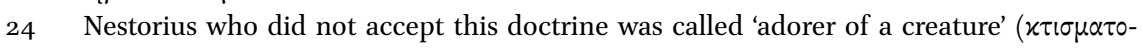
$\lambda \dot{\alpha} \tau p \eta \varsigma)$. See Leontius of Byzantium, Complete Works, edited by B. E. Daley (Oxford, 2017), p. 424, p. 43 .

25 For a fuller discussion of Leo's position and a survey of scholarly literature see my article 'Adoring Christ's Image'.

26 On the historical setting of the controversy, see most recently P. T. Bara, Leo of Chalcedon: The Network, Paideia, and Miracles of an Early Komnenian Metropolitan (PhD thesis, University of Szeged, 2020).

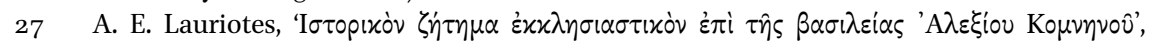

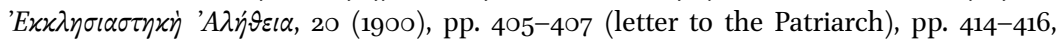
pp. 445-447 (letter of Nicholas of Adrianople). 
The imprint of Christ, which is divinely hypostasised, that is, which has gained hypostasis in the very hypostasis of the Son of God, and which is therefore itself God, because the Son has been substantially conjoined and is conjoined with it (sc. the imprint) so that it cannot be separated and pulled apart, is also venerated adorationally in his holy images and is worshipped as God. ${ }^{28}$

The linchpin of the argument is the hypostatic union, which divinises Christ's human nature through contact with his divine nature. Leo argues that the personal features, which individuate the human nature, such as the colour of the eyes or the shape of the nose, must also be divinised, since they, too, are part of the hypostasis of Christ. As such they can be venerated as God.

This was a universally accepted theological position. Yet Leo goes one step further. He claims that the representation of Christ's outward appearance on images is also assumed into the divine hypostasis and therefore worthy of adoration. Then he also speaks about the two other divine hypostases.

The Father who is without beginning, and his Son who is equally without beginning even after the incarnation, and the all-holy Spirit who is equally without beginning, are co-venerated adorationally through one veneration, but the incarnated only-begotten Son of the Father when seen by himself and his more-than-holy imprint is venerated adorationally through one veneration. For his flesh and its imprint are not covenerated with his divinity, but having been conjoined with it, as regards substance, as the Theologian says, and always being conjoined with it (sc. the divinity), it is one hypostasis with it (sc. the divinity), and one not as regards nature but as regards concurrence. Therefore his flesh and its imprint are venerated adorationally but not co-venerated with him (sc. the Son). ${ }^{29}$

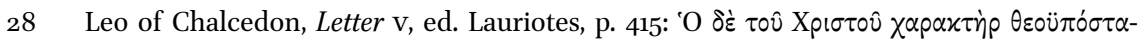

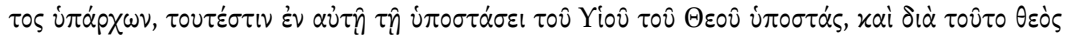

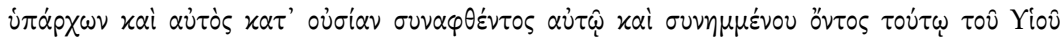

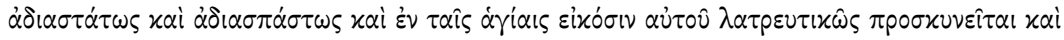

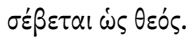

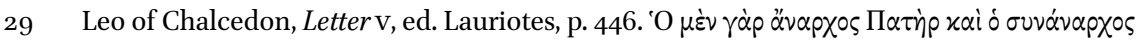

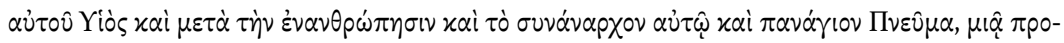

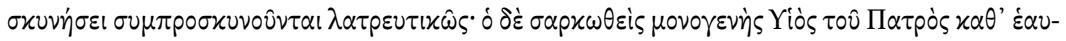

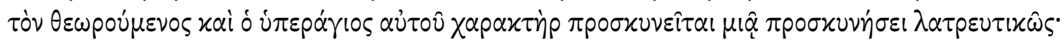

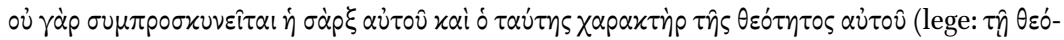

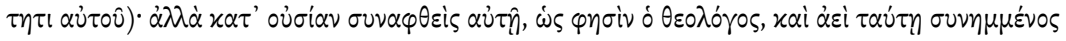


Here Leo creates a nexus between image theology and Trinitarian theology. Father, Son and Spirit are God and therefore worthy of adoration. But since they are three hypostases they can be adored individually. One can say: 'I adore the Father, the Son and the Spirit.' By contrast, the representation, when seen by itself, is a creature. Therefore one cannot say: 'I adore the Father, the Son, the Spirit and the representation of the incarnated Son. This is an argument that we have already found in Theodore. Yet Leo then makes the step that Theodore has shrunk from. He declares that the representation is part of the hypostasis of the incarnated Son and can thus be adored.

It is evident that Leo merely spells out the implications of Theodore's view about the one hypostasis. Yet this means that he has no place for relational veneration, which Theodore had defended in many of his writings. Since he could not simply suppress it he had to give it a different meaning.

The material aspect of the image is venerated through honour and relationally, that is, because of the relation to the divinely hypostasised character of Christ, whereas the imprint that is seen in it is venerated adorationally not because of another but itself because of itself. ${ }^{30}$

This argument for the first time gives a positive value to the material aspect. It is not divinised through assumption into the divine hypostasis but it nevertheless deserves veneration. Yet one may ask whether it was not already implied by Theodore. As we have seen, in Letter 546 he states that the twoness that makes relation possible is only found in the different substances of the image and the archetype.

\section{3}

\section{Eustratius of Nicaea}

Leo's views on icon worship did not go unchallenged. Eustratius, a patriarchal cleric who later became metropolitan of Nicaea, took up the pen against him. Eustratius was schooled in philosophy and made ample use of syllogistic reasoning not only in his writings about other theological topics but also in his

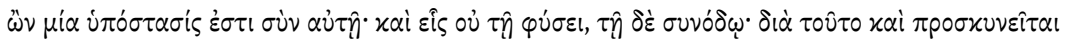

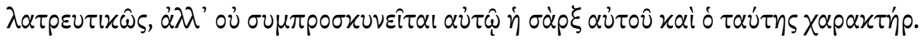

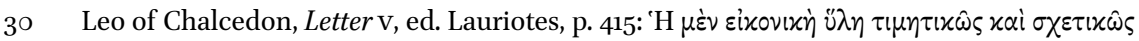

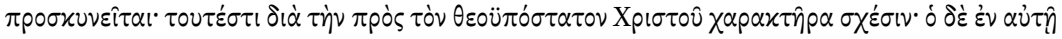

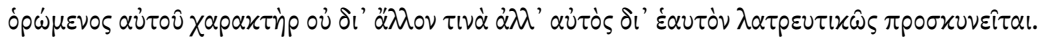


polemic against Leo. ${ }^{31}$ This polemic consists of a dialogue with a partisan of Leo, the so-called Lover of Truth, and a treatise, the so-called Demonstration. ${ }^{32}$ Both texts are quite different in character. The dialogue is long-winded and rambling, and contains many digressions that have little to do with the question of adoration, whereas the treatise is concise and to the point. Since they are quite similar in content I will limit the discussion to the treatise. In its concluding paragraph Eustratius claims that he defends tradition against the newfangled notions of Leo.

The Fathers have taught us that the honour and the veneration, which we give to the holy images, is relational and not adorational, since they have a relation to their own prototypes. And this tradition has been proclaimed everywhere by those divinely inspired ones whereas they have never been found to hand down to us an adoration of the image or in the image but indeed they have striven to eliminate as impious that which has thus been opined or said. ${ }^{33}$

Eustratius' contention that he is merely defending orthodoxy is not without justification. We have seen that in Letter 474 Theodore advocates relational veneration and castigates the adoration of images as a blasphemous practice. There, Eustratius could also have found a precedent for his further claim that the same kind of veneration is given to the image of Christ as to the images of the saints. ${ }^{34}$

Eustratius was aware that Leo's argument proceeded in two steps: the one hypostasis of the divine Word assumes into itself and thereby divinises firstly the human nature with its individual characteristics and secondly the representations of these characteristics on images. He clearly felt that he could not reject the second step if he had not already tackled the first. Accordingly, he

31 See e.g. M. Trizio, Il neoplatonismo di Eustrazio di Nicea (Biblioteca filosofica di Quaestio, 23; Bari, 2016), pp. $3^{-17}$, for the biography of Eustratius and a brief description of his oeuvre.

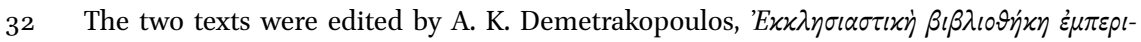

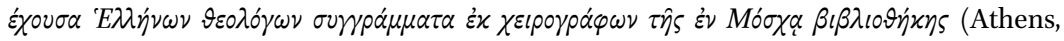
1866), pp. 127-151, pp. 151-16o.

33 Eustratius of Nicaea, Demonstration, ed. Demetrakopoulos, pp. 159-160: $\Sigma \chi \varepsilon \tau 1 x \dot{\eta} \nu \delta \varepsilon \dot{\eta} \dot{\eta} \mu \hat{\alpha} \varsigma$

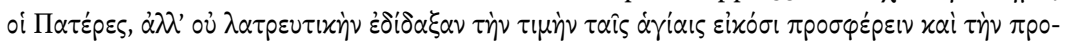

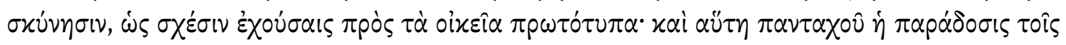

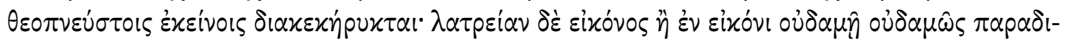

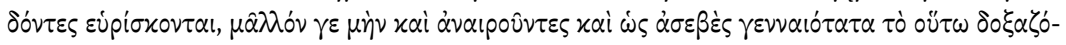
$\mu \varepsilon v o v$ ทे $\lambda \varepsilon \gamma o ́ \mu \varepsilon v o v$.

Eustratius of Nicaea, Demonstration, ed. Demetrakopoulos, p. 159. 
begins by speaking about Christ's humanity to which he refers as 'that which is assumed'.

The God Word is the same as the Father and the Spirit as regards substance. That which is assumed is not the same as the Father and the Spirit as regards substance. Consequently, that which is assumed is not the same as the God Word as regards substance. ${ }^{35}$

Whereas Leo had focused on the hypostatic dimension Eustratius foregrounds the substantial aspect. This was a shrewd move since it was universally agreed that the divine nature was radically different from the human one. His strategy is to consider the human substance in isolation. He declares that it is a creature and that it has three dimensions, which rules out that it can be adored but at the same time makes it depictable.

Yet he cannot simply disregard the hypostatic dimension since it was an intrinsic part of Christian doctrine.

Consequently, that which is assumed is not adorable by itself, but because of the divinity, which is united with it in a hypostasis, so that adoration is offered to the divinity by itself but that which is assumed enjoys it, too, as also the divinisation itself and the other things, which it can have through the manner of exchange. But if that which is assumed is not adorable by itself but is depictable by itself, it does consequently not have adorability as being depictable. ${ }^{36}$

Here Eustratius admits that the human nature of Christ can be adored because it has been assumed into the hypostasis of Christ. Yet then he immediately returns to his original argument. It is difficult to see how such reasoning could be valid, in particular since Eustratius offers no further explanation. It might be argued that in an image only Christ's humanity is depicted since the divinity

35 Eustratius of Nicaea, Demonstration, ed. Demetrakopoulos, p. 152: 'O $\Theta$ zòs $\Lambda$ óyos ó aủzòs

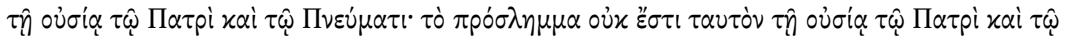

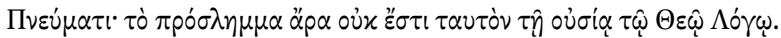

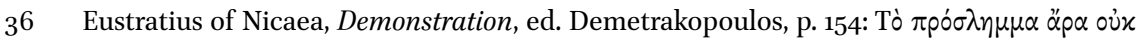

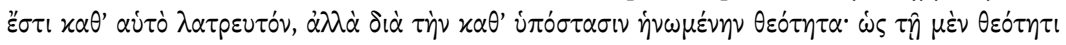

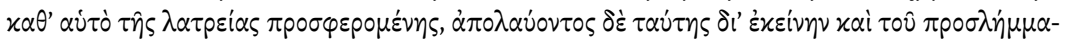

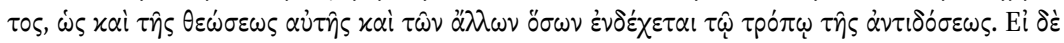

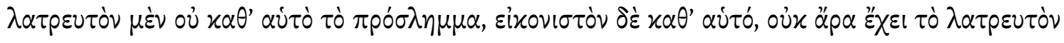

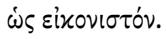


is not depictable. As such it would be seen in isolation and therefore not be worthy of adoration.

Leo had only shown interest in the human nature insofar as it was the carrier of personal features, which alone could be found in representations. Eustratius agrees with him that the human nature as such cannot be depicted. Yet the conclusions he draws from this fact are radically different.

Further, the image receives the shape and the form of that which is depicted, not the substance. But the shape and the form is a mere quality and the fourth kind of quality. But every mere quality is an accident. But no accident is adorable. Consequently, shape or form are in no way adorable. ${ }^{37}$

Here Eustratius makes the point that individual characteristics cannot be adored because they are accidents and thus ontologically even more inferior than created substances. Since they are also found in the prototype this would be true not only for the representation of Christ but also for Christ himself. In this case Eustratius is surprisingly unguarded. He bluntly states that no accident is adorable without adding the qualification 'when considered by itself'. Thus he gives the impression that the individual characteristics of Christ's human body are not included in the divine hypostasis. This was hardly an orthodox position even though nobody seems to have objected to it at the time. Significantly, Eustratius later developed similar arguments in his treatises against the Monophysite Armenians where the focus is on Christology and the specific topic of image worship is not broached. It was at this point that he fell foul of the authorities and was condemned as a Nestorian. ${ }^{38}$

In his treatise Eustratius not only sets out his own position but also rebuts arguments that his opponents put forward in order to justify their position.

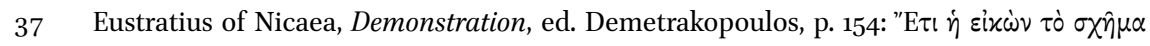

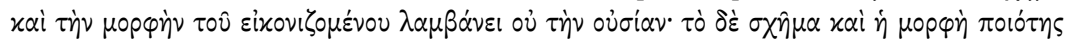

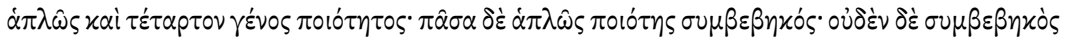

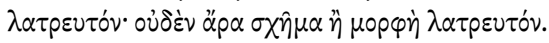

38 See B. Lourié, 'Une dispute sans justes: Léon de Chalcédoine, Eustrate de Nicée et la troisième querelle sur les images sacrées', $S P, 42$ (2006), pp. 321-340, esp. pp. 238-240; and idem, 'Eustratus of Nicaea, a Theologian: About the Recent Publications of Alexei Barmin', Scr, 16 (2020), pp. 344-358, esp. pp. 351-355. 
But some say: 'We do not offer adoration by taking the form in the image but we separate the character from the matter, as being divinely hypostasised, and deign it worthy of adoration. ${ }^{39}$

We have already found a similar statement in Theodore's Letter 546 , albeit without a reference to the identity of hypostasis in the context. Eustratius objects that the mental operation by which one abstracts the representation from the image does not make the representation divine. He points out that the imprint is stored in the human mind where it can be retrieved from memory. As such it is as corporeal as when it is seen on an image. Eustratius' adversaries, following the lead of Leo, defend their position by claiming that there is only one hypostasis.

But if they say again, that the image and the prototype are not two hypostases, and that for this reason the painter of the icon paints him who is depicted, I wonder if they do not wrongly understand that which has been said by the divine Fathers, that the image and the prototype are not two hypostases. ${ }^{40}$

This position can be traced back to Theodore. As we have seen he repeatedly states that Christ and his representation are one hypostasis and not two. Yet if it is correctly reproduced by Eustratius, it goes beyond what Theodore had said. It gives the impression as if the painter of the image created or multiplied the divine hypostasis. Such a position is manifestly absurd, which makes it easy for Eustratius to score a point. The second objection is more weighty.

For it is not one hypostasis of such a kind that together with the idioms, the substance of the prototype, too, subsists in the image but it is hypostasis whereas they (sc. the idioms) do not subsist by themselves but imitate in matter of different nature that which subsists, for they are enmattered shapes and numbers which subsist in others, but do not subsist by themselves. ${ }^{41}$

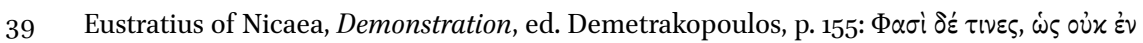

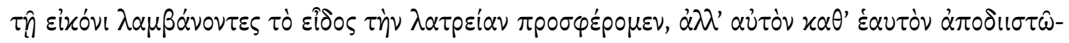

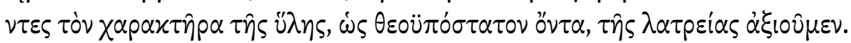

40 Eustratius of Nicaea, Demonstration, ed. Demetrakopoulos, p. 158: El $\delta \dot{\varepsilon} \pi \dot{\alpha} \lambda l v \varphi \alpha \sigma i v$, $\dot{\omega} \varsigma$

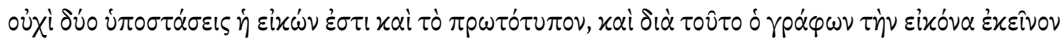

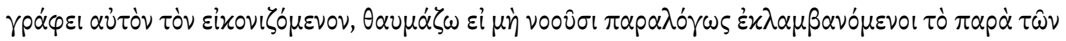

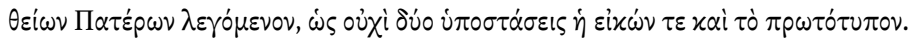

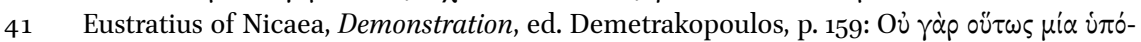

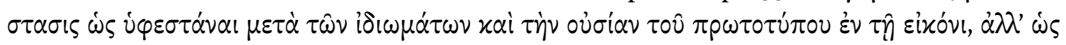


Eustratius declares that one could only speak of one hypostasis if the image, too, possessed not only the individual characteristics but also the substance of Christ's humanity. He rejects the extreme separation of the two components in Theodore's image theology, which reduces the hypostasis to a bundle of accidents. ${ }^{42}$ This had always been a problematic feature since it ran counter to the use of the term in the Christological discourse, where hypostasis denotes concrete and independent existence. ${ }^{43}$ Such existence is only possible if the individual characteristics are complemented with a substance that confers reality on them. Eustratius points out that this is true for Christ himself but not for the characteristics seen in an image since they are nothing but an imitation of a hypostasis in an extraneous matter.

In his letters and treatises Theodore of Stoudios spoke about the ontological bond between Christ himself and his representation on an image in two ways. Firstly, he declared that they are archetype and derivate, linked through the category of relation; and secondly, they constitute one hypostasis. In the former case the difference between the two entities is preserved whereas in the latter case they are identical. Theodore never resolved this tension. He insisted that the image must be venerated but not adored as if it were divine. Almost three hundred years later Leo of Chalcedon focused exclusively on the sameness of hypostasis. He declared that the representation on an image is part of the hypostasis of Christ and therefore must be adored as divine. Leo was in turn attacked by Eustratius, the later metropolitan of Nicaea. Eustratius advocated relational veneration, which is also found in Theodore's writings. Yet in his attempts to refute Leo's views he went so far as to declare that not only Christ's representation on an image but also Christ's human nature was not divine. Such a position was not reconcilable with orthodox doctrine.

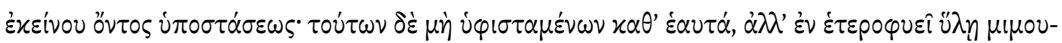

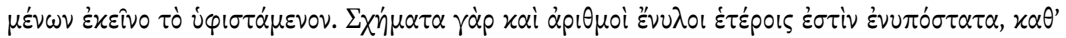
$\dot{\varepsilon} \alpha u \tau \dot{\alpha} \delta \dot{\varepsilon}$ ởx $\dot{u} \varphi \hat{i} \sigma \tau \alpha \tau \alpha \mathrm{l}$.

42 In Christology this problem does not arise since the human nature is divinised and the characteristics that inhere in it are then also divinised. In image theology, on the other hand, only the characteristics but not the substance is divinised.

43 See e.g. D. Krausmüller, 'Under the spell of John Philoponus: How Chalcedonian theologians of the late Patristic period attempted to safeguard the oneness of God', Journal of Theological Studies, 68 (2017), pp. 625-649, esp. p. 630. 